\title{
Hubungan Antara Perilaku Cybersex dengan Pre-Marital Sex pada Mahasiswa Universitas X di Kota Bandung
}

\author{
Sarah Fathia Puteri *, Indri Utami Sumaryanti \\ Prodi Psikologi, Fakultas Psikologi, Universitas Islam Bandung, Indonesia. \\ sarah.fathia.puteri@gmail.com,indri.utami@unisba.ac.id
}

\begin{abstract}
With the development of the internet that is increasingly fast and easy to access, a person or especially students, it is easier to see content that is inappropriate for viewing, such as adult advertisements, Western and local movie streaming sites that are not censored by related institutions, and also pornographic content on social media or on certain websites. On the other hand, at around the age of early adulthood or at the level of students, is the age of exploration of things that smelled of sex and consider it a matter of course, so that more and more pre-marital sexual behavior appears or premarital sex. There are differences in the results of research that researchers have explored, namely 6 studies that said that the two things had a relationship and 1 study said it had a weak relationship. After researchers interviewed 20 University X students, 14 of them had committed cybersex behavior with pre-marital sex. Because of differences in research and phenomena at the University X, researchers are interested in examining the relationship between cybersex behavior and pre-marital sex in University X students who are in Bandung. Respondents in this study were 122 students. The theory used in this study is the cybersex theory from Canners, Delmonico, and Griffin (2001) and the pre-marital sex theory from Duvall and Miller (2005). The correlation results show a correlation coefficient of 0.469 with a significance level of 0.000 which indicates that there is a close positive relationship between cybersex and pre-marital sex.
\end{abstract}

Keywords: Cybersex, Pre-marital Sex, Students, University.

\begin{abstract}
Abstrak. Dengan berkembangnya internet yang semakin pesat dan mudah untuk di akses, seseorang atau khususnya mahasiswa, menjadi lebih mudah melihat konten yang kurang pantas untuk dilihat, seperti iklan-iklan dewasa, situs-situs streaming film Barat maupun lokal yang tidak disensor oleh lembaga terkait, dan juga konten pornografi di media sosial atau pada website tertentu. Di sisi lain, pada usia sekitar dewasa awal atau pada tingkatan mahasiswa, adalah usia eksplorasi pada hal-hal yang berbau seksual dan menganggap hal tersebut adalah hal yang biasa, sehingga semakin banyak muncul perilaku seksual pranikah atau pre-marital sex. Terdapat perbedaan hasl penelitian yang telah peneliti telusuri, yaitu 6 penelitian yang mengatakan bahwa kedua hal tersebut memiliki hubungan dan 1 penelitian mengatakan memiliki hubungan yang lemah. Setelah peneliti mewawancarai 20 orang mahasiswa Universitas X, 14 diantaranya pernah melakukan perilaku cybersex dengan pre-marital sex. Karena adanya perbedaan penelitian dan fenomena pada Universitas X tersebut, peneliti tertarik untuk meneliti hubungan antara perilaku cybersex dengan pre-marital sex pada mahasiswa Universitas X yang berada di Kota Bandung. Responden dalam penelitian ini adalah 122 orang mahasiswa. Teori yang digunakan dalam penelitian ini adalah teori cybersex dari Canners, Delmonico, dan Griffin (2001) serta teori premarital sex dari Duvall dan Miller (2005). Hasil korelasi menunjukkan koefisien korelasi sebesar 0.469 dengan taraf signifikasi 0.000 yang menunjukkan bahwa terdapat hubungan positif yang erat antara cybersex dengan pre-marital sex.
\end{abstract}

Kata Kunci: Cybersex, Pre-marital Sex, Mahasiswa, Universitas. 


\section{A. Pendahuluan}

Hasil data survey Komisi Perlindungan Anak Indonesia (KPAI) menyebutkan bahwa sebanyak 32\% remaja usia 14-18 tahun di kota-kota besar Indonesia (Bandung, Jakarta, dan Surabaya) pernah berhubungan seks pranikah. Dari survey KPAI tersebut diketahui bahwa salah satu pemicu utama dari perilaku remaja tersebut adalah muatan pornografi yang diakses via internet (Ika, 2011).

Menurut penelitian dari Uecker (2015), perilaku seks pranikah merupakan permasalahan sekaligus fenomena sosial yang kian lazim dijumpai di dalam masyarakat. Pergeseran norma baik-buruk dan benar-salah, terutama dalam konteks seksualitas semakin jelas terlihat. Pada kelompok remaja, perilaku seks pranikah semakin dianggap normatif dan menjadi hal yang tabu lagi seperti dahulu. Salah satu bentuk perilaku seks pranikah yang paling permisif adalah dilakukannya hubungan seks. Mahasiswa sendiri telah lama disebutkan sebagai kelompok yang rentan sekaligus juga aktif terlibat dalam perilaku seks pranikah.

Di sisi lain, terdapat beberapa penelitian yang menyatakan bahwa tidak ada keterkaitan antara perilaku cybersex dengan pre-marital sex (perilaku seksual pranikah), seperti penelitian yang dilakukan oleh Murti (2008) yang menyebutkan bahwa tidak ada hubungan bermakna antara usia, paparan pornografi di media massa, frekuensi paparan melalui majalah, koran, tabloid, novel, televisi, radio, games PC, telfon seks dengan tingkat perilaku seksual siswa.

Ani dkk. (2010) melakukan penelitian dengan subjek sebanyak 1415 siswa sebagai responden, dan dari penelitian tersebut disimpulkan bahwa hasil penelitian tidak menunjukkan bukti yang kuat adanya hubungan sebab akibat antara pemaparan pornografi dengan perilaku seksual siswa.

Terdapat juga penelitian dari Aidil (2014) yang mengemukakan bahwa frekuensi paparan pornografi tidak memiliki hubungan yang signifikan dengan perilaku seksual.

Penelitian oleh Uci dkk. (2014) menyimpulkan bahwa dari hasil penelitian yang diuji menggunakan uji regresi logistik berganda, menunjukkan bahwa variabel yang paling berpengaruh pada perilaku seksual remaja adalah adaptasi dengan peer group.

Sudirman (2015) melakukan penelitian dengan sampel sebanyak 117 orang remaja, menyebutkan bahwa hasil dari analisis regresi logistik yang telah diuji, ditemukan bahwa variabel yng paling dominan berkontribusi terhadap terjadinya perilaku seksual remaja adalah kontrol diri.

Dalam penelitian Hasli dkk. (2016) dengan sampel sebanyak 99 orang responden menyebutkan bahwa tidak ada hubungan yang signifikan antara jumlah keterpaparan materi pornografi terhadap perilaku seksual remaja di Pekanbaru.

Penelitian yang dilakukan oleh Abadi (2015) dengan subjek sebanyak 187 responden mengatakan bahwa ada hubungan yang sangat lemah antara mengakses pornografi melalui fasilitas handphone dengan perilaku seksual remaja usia 16-19 tahun di SMA Muhammadiyah Kota Malang.

Dari beberapa penelitian tersebut, dapat disimpulkan bahwa kedua hal tersebut juga tidak selalu berkaitan.

Peneliti mewawancarai 20 orang mahasiswa di Universitas X di Kota Bandung, dan 14 dari 20 orang tersebut pernah melakukan perilaku cybersex, seperti menonton tayangan pornografi, chat sex, phone sex, dan videocall sex. Selain itu, mahasiswa tersebut juga pernah melakukan perilaku seksual pranikah (pre-marital sex), seperti dari yang paling ringan, yaitu berpegangan tangan, sampai dengan tahapan paling berat, yaitu sexual intercourse. Berdasarkan hasil wawancara yang didapatkan, pada universitas ini pun terdapat beberapa mahasiswa yang hamil diluar nikah karena melakukan pre-marital sex (perilaku seksual pranikah).

Dari yang telah dipaparkan diatas, seperti perbedaan dari hasil penelitian,, hasil wawancara dan fenomena yang terjadi pada Universitas $\mathrm{X}$ tersebut, serta penelitian tentang cybersex yang masih jarang dikaitkan dengan pre-marital sex, peneliti tertarik ingin melakukan penelitian untuk mengetahui hubungan perilaku cybersex terhadap pre-marital sex 
pada universitas tersebut dengan mengangkat judul "Hubungan Antara Perilaku Cybersex dengan Pre-marital Sex pada Mahasiswa Universitas X di Kota Bandung".

\section{B. Landasan Teori}

Menurut Carners, Delmonico, dan Griffin (2001) cybersex adalah mengakses pornografi di internet, yang terlibat dalam real-time yaitu percakapan tentang seksual online dengan orang lain, dan mengakses multimedia software. Delmonico dan Miller (2009) menyebutkan lima aspek yang terdapat pada cybersex, yaitu:

Online Sexual Compulsivity

Adanya perilaku berkelanjutkan melakukan seksual online meskipun terdapat konsekuensi yang signifikan dan adanya pemikiran yang obsesif terkait dengan perilaku seksual online.

\section{Online Sexual Behaviour Social}

Kecenderungan untuk terlibat dalam interaksi interpersonal dengan orang lain selama perilaku seksual online, seperti email, ruang obrolan, dan lain sebagainya yang berhubungan dengan konteks seksual.

\section{Online Sexual Behaviour-Isolated}

Seseorang yang melakukan cybersex biasanya memiliki interaksi interpersonal yang terbatas dengan orang lain, seperti menghabiskan waktu untuk menonton tayangan pornografi.

\section{Online Sexual Spending}

Sejauh mana seseorang menghabiskan uang untuk mendukung aktivitas seksual onlinenya dan konsekuensi yang terkait dengan pengeluaran tersebut.

\section{Interest in Online Sexual Behavior}

Kecenderungan seseorang untuk menggunakan komputer untuk tujuan seksual, seperti menandai situs yang berbau seksual.

Menurut Duvall dan Miller (2005), terdapat beberapa bentuk perilaku seksual pranikah, yaitu:

1. Bersentuhan (touching)

Berpegangan tangan, berpelukan, berangkulan.

2. Berciuman (kissing)

Batasan perilaku ini mulai dari hanya sekedar kecupan (light kissing) sampai pada French kiss (deep kissing).

3. Bercumbu (petting)

Segala kegiatan dengan tujuan untuk membangkitkan gairah seksual, seperti berupa sentuhan, rabaan pada daerah erogen atau erotis, tetapi belum sampai melakukan hubungan kelamin (sexual intercourse)

4. Berhubungan badan (sexual intercourse)

Adanya kontak antara penis dengan vagina dengan terjadinya penetrasi penis kedalam vagina. 
C. Hasil Penelitian dan Pembahasan

Hubungan Antara Perilaku Cybersex dengan Pre-marital Sex Pada Mahasiswa Universitas X di Kota Bandung

Responden dalam penelitian ini merupakan seluruh mahasiswa program sarjana yang aktif di Universitas X di Kota Bandung yang berjumlah 122 orang. Responden dari penelitian ini didapatkan dari kriteria yang pernah melakukan perilaku cybersex.

Berdasarkan hasil data yang diperoleh, kelima aspek dari cybersex memiliki hubungan yang positif dengan keempat kategori pre-marital sex, sehingga semakin tinggi aspek cybersex, semakin tinggi juga kategori pre-marital sex, begitupun sebaliknya. Aspek online sexual behavior-social pada cybersex dengan kategori touching pada pre-marital sex memiliki nilai koefisien korelasi yang paling tinggi, yaitu sebesar 0.522 yang berarti kedua variabel tersebut termasuk dalam kategori yang cukup kuat. Sedangkan untuk nilai koefisien korelasi yang paling rendah yaitu terdapat pada aspek online sexual spending pada cybersex dengan kategori touching pada pre-marital sex, yaitu sebesar 0.232 yang berarti kedua variabel tersebut termasuk dalam kategori sangat lemah.

Maka dari itu, dapat disimpulkan bahwa adanya kecenderungan untuk terlibat dalam interaksi interpersonal dengan orang lain selama perilaku seksual online, seperti e-mail, ruang obrolan, dan lain sebagainya memiliki hubungan yang cukup kuat untuk melakukan perilaku berpegangan tangan, berpelukan dan berangkulan.

Sedangkan dengan sejauh mana seseorang menghabiskan uang untuk mendukung aktivitas seksual onlinenya dan konsekuensi yang terkait dengan pengeluaran tersebut, memiliki hubungan yang sangat lemah untuk melakukan perilaku berpegangan tangan, berpelukan, dan berangkulan.

Berdasarkan jenis kelamin, mahasiswa yang menjadi responden terdiri dari 63 orang perempuan atau menurut persentase adalah $51 \%$, dan 59 orang laki-laki atau menurut persentase yaitu $49 \%$.

Berdasarkan tahun akademik, mahasiswa yang menjadi responden terdiri dari angkatan 2014 sebanyak 4 orang atau dalam persentase sebesar 3.27\%, angkatan 2015 sebanyak 52 orang atau $42.63 \%$, angkatan 2016 sebanyak 28 orang atau $22.95 \%$, angkatan 2017 sebanyak 25 orang atau $20.49 \%$, dan angkatan 2018 sebanyak 13 orang atau $10.65 \%$.

Berdasarkan usia, mahasiswa yang menjadi responden terdiri dari usia 18 tahun yang berjumlah 3 orang atau dalam bentuk persentase yaitu 2.4\%, usia 19 tahun berjumlah 21 orang atau $17.2 \%$, usia 20 tahun berjumlah 13 orang atau $10.6 \%$, usia 21 tahun berjumlah 33 orang atau $27 \%$, usia 22 tahun berjumlah 42 orang atau 34.4\%, dan usia 23 tahun berjumlah 10 orang atau $8.1 \%$.

Berdasarkan hasil data yang diperoleh, persentase mahasiswa yang melakukan perilaku cybersex dalam aspek Online Sexual Compulsivity yaitu sebesar 29\%, aspek Online Sexual Behaviour-Social yaitu sebesar 21\%, aspek Online Sexual Behaviour-Isolated yaitu sebesar 21\%, aspek Online Sexual Spending yaitu sebesar 6\%, dan aspek Interest in Online Sexual Behavior yaitu sebesar 23\%.

Jumlah mahasiswa yang melakukan perilaku cybersex dalam aspek Online Sexual Compulsivity yaitu sebanyak 111 orang dari 122 responden, aspek Online Sexual BehaviourSocial yaitu sebanyak 78 orang dari 122 responden, aspek Online Sexual Behaviour-Isolated yaitu sebanyak 80 orang dari 122 responden, aspek Online Sexual Spending yaitu 24 orang dari 122 reponden, dan aspek Interest in Online Sexual Behavior yaitu sebanyak 86 orang dari 122 responden.

Dari hasil data yang diperoleh, terdapat 52 orang yang termasuk dalam karakteristik rendah (low risk group), yang terdiri dari 46 orang perempuan, dan 6 orang laki-laki. Menurut teori, dapat dikatakan bahwa 52 orang mahasiswa Universitas X mungkin atau mungkin tidak memiliki masalah dengan perilaku seksual di internet. Pada karakteristik sedang (at-risk) terdapat 37 orang yang terdiri dari 11 orang perempuan dan 26 orang laki-laki. Menurut teori, dapat dikatakan bahwa 37 orang mahasiswa Universitas X berisiko adanya perilaku seksual yang mengganggu area signifikan kehidupan seseorang. Sedangkan pada aspek tinggi (highest risk) terdapat 33 orang yang terdiri dari 6 orang perempuan dan 27 orang laki-laki. Menurut 
teori, dapat dikatakan bahwa 33 orang mahasiswa Universitas $\mathrm{X}$ berisiko paling tinggi untuk mengganggu dan membahayakan bidang-bidang penting dalam kehidupan seseorang (sosial, pekerjaan, pendidikan, dan lain-lain). Dapat disimpulkan bahwa pada karakteristik rendah (low risk group) lebih banyak terdapat pada mahasiswa perempuan, yang berarti mahasiswa perempuan pada Universitas $X$ lebih kecil memiliki risiko untuk memiliki masalah dengan perilaku seksual di internet. Pada karakteristik sedang (at-risk), lebih banyak terdapat pada mahasiswa laki-laki, yang berarti mahasiswa laki-laki pada Universitas X lebih memiliki risiko dengan perilaku seksual ysng mrnggsnggu area signifikan seseorang. Pada kategori tinggi (highest risk), lebih banyak terdapat pada mahasiswa laki-laki, yang berarti mahasiswa laki-laki pada Universitas $X$ lebih memiliki risiko paling tinggi untuk mengganggu dan membahayakan bidang-bidang penting dalam kehidupan seseorang.

\section{Kesimpulan}

Berdasarkan penelitian mengenai hubungan cybersex dengan pre-marital sex pada mahasiswa Universitas X di Kota Bandung, didapatkan simpulan sebagai berikut:

1. Cybersex hubungan yang positif dengan pre-marital sex. Hal tersebut dapat dilihat dari koefisien korelasi yang cukup kuat antara cybersex dengan Pre-marital sex. Koefisien korelasi yang didapatkan sebesar 0.469 dengan nilai signifikansi 0.000 yang berarti semakin rendah cybersex mahasiswa maka akan semakin rendah pula pre-marital sex yang dimiliki mahasiswa begitupun sebaliknya.

2. Keempat aspek cybersex memiliki hubungan yang positif dengan pre-marital sex. Hal tersebut dapat dilihat dari koefisien korelasi positif antara keempat aspek cybersex dengan pre-marital sex.

\section{E. Saran}

Mempertimbangkan hasil penelitian bahwa berdasarkan hasil penelitian yang telah dilakukan, peneliti memberikan saran bagi beberapa pihak sebagai berikut :

1. Karena terdapat perilaku cybersex dan pre-marital sex pada Universitas X tersebut, diberikan bimbingan tentang cybersex dan pre-marital sex agar perilaku tersebut tidak semakin berdampak buruk bagi mahasiswa.

\section{Daftar Pustaka}

[1] Amrillah, A. A., Prasetyaningrum, J., Hertinjung, W. S. 2007. Hubungan Antara Pengetahuan Seksualitas dan Kualitas Komunikasi Orang Tua - Anak dengan Perilaku Seksual Pranikah. Indigeneous, 7 (4). pp. 45-50. ISSN 0854-2880 (In Press)

[2] Andini, S. (2006). Perbedaan sikap terhadap cybersex berdasarkan jenis kelamin pada dewasa awal. Skripsi yang tidak dipublikasikan, Universitas Gunadarma. Fakultas Psikologi, Jakarta, Indonesia.

[3] Asosiasi Penyelenggara Jasa Internet Indonesia (APJII). (2018). Hasil Survei Penetrasi dan Perilaku Pengguna Internet Indonesia. Jakarta : Pusakom UI.

[4] Berk, E.L. (2012). Development Through The Lifespan. Yogyakarta: Pustaka Pelajar

[5] BKKBN. Kajian Profil Penduduk Remaja (10-24 tahun). Pusat Penelitian dan Pengembangan Kependudukan. BKKBN. Seri 1(6): 2011

[6] Carnes, P. J., Delmonico, D. D. \& Griffin, E. J. (2001) Internet addiction: Hazelden Foundation.

[7] Cooper, A. (2002). Sex and the internet. U.S.A.: Brunner-Routledge.

[8] Christensen B, Hyde R (2010). The brain science behind internet pornography addiction. White Paper Series

[9] Feist, J. \& Gregory J. Feist. (2010). Teori Kepribadian (Edisi ketujuh) Jakarta: Penerbit Salemba Humanika.

[10] Hikmah, Annisaa Ul (2013). Hubungan Akses Media Pornografi Internet dengan Sikap 
Seksual Pranikah Pada Remaja Kelas XI di SMA Negeri Bambanglipuro Bantul Yogyakarta Tahun 2013. Sekolah Tinggi Ilmu Kesehatan 'Aisyiyah Yogyakarta

[11] Huwaidah, Rizka (2018). Perilaku Cybersex dan Dampaknya pada Perilaku Seks Pranikah Mahasiswa (Studi Kualitatif pada Mahasiswa di Kabupaten Jember). Universitas Jember

[12] Mardyantari, E., dkk. (2018). Hubungan Media Pornografi dengan Perilaku Seksual Pranikah pada Remaja. Fakultas Kesehatan Universitas Udayana

[13] Muhammad Randy Sanjaya, 2014 Hubungan antara Persepsi Seks Bebas dengan Perilaku Seksual Pada Komunitas Motor di Bandung Universitas Pendidikan Indonesia

[14] Murti, Indah Rachma (2008). Hubungan Antara Frekuensi Paparan Pornografi Melalui Media Massa dengan Tingkat Perilaku Seksual Pada Siswa SMU Muhammadiyah 3 Tahun 2008. Universitas Indonesia

[15] Pahlawan, Robi'i dkk (2

[16] Santrock, J.W. (2012). Life-span development (rev Ed). Jakarta: Penerbit Erlangga

[17] Sarwono, Sarlito Wirawan. 2001. Psikologi Remaja. Jakarta: Raja Grafindo Persada

[18] Septianti, Andi Lestari (2014). Upaya Penanggulangan Kejahatan Pornografi dalam Media Internet Oleh Pihak Kepolisian di Kota Makassar (Studi Kasus Polrestabes Makassar. Hasanuddin University

[19] Sprecher, S. (2002). Sexual satisfaction in premarital relationships: Associations with satisfaction, love, commitment, and stability. The Journal of Sex Research, 39(3), 190196. doi: 10.1080/00224490209552141. Sprecher, S., Treger, S., \& Sakaluk, J. K. (2013). Premarital sexual standards and sociosexuality: Gender, ethnicity, and cohort differences. Archives of Sexual Behavior, 42(8), 1395-1405. doi: 10.1007/s10508-0130145-6

[20] Sudirman, Rany Maulany (2015). Peran Teman Sebaya dan Paparan Media Pornografi Terhadap Perilaku Seksual Remaja di Sekolah Menengan Pertama Kejuruan Tunas Bangsa Kabupaten Subang. Universitas Gadjah Mada

[21] Uecker, J. E. (2015). Social context and social intercourse among first-year students at selective colleges and universities in the United States. Social Science Research, 52, 5971. doi: 10.1016/j.ssr esearch.2015.01.005

[22] Young J., Boies S.C. (2004). The internet, sex, and youths: Implication for sexual development. Sexual Addiction \& Compulsivity. Taylor \& Francis

[23] Yutifa, Hasli (2016). Hubungan Paparan Pornografi Mellui Elektronik Terhadap Perilaku Seksual Remaja. Universitas Riau 